\title{
Fading and transformation: how a woman entrepreneur's multiple identities interact throughout her life
}

\author{
Francesca Maria Cesaroni, Annalisa Sentuti and \\ Maria Gabriella Pediconi \\ Department of Economics, Society, Politics (DESP), University of Urbino Carlo Bo, \\ Urbino, Italy
}

\begin{abstract}
Purpose - This paper aims to further the understanding of women entrepreneurs' multiple identities by exploring how they interact throughout women's life cycles.

Design/methodology/approach - This article combines a case study and a narrative analysis to investigate the experience of a woman who founded a business and retired after passing it on to her son. Data were collected by combining two different methods: biographical interview and follow-up interviews or conversations.

Findings - Findings show that interactions between a woman entrepreneur's multiple identities may evolve through two main processes of change: transformation and fading. In the transformation process, adverse interactions between identities turn into synergistic and fruitful relationships. In the fading process, conflicts between identities gradually disappear, giving way to peaceful coexistence. Women's agency proves paramount in making these processes possible and helping her achieve personal and professional fulfillment. Originality/value - In prior studies, women entrepreneurs have mostly been observed at a specific time or stage in their life and entrepreneurial experience. This paper responds to the call for the adoption of a dynamic perspective in the analysis of interactions among a woman entrepreneur's multiple identities so as to show how they may evolve during her entrepreneurial experience.
\end{abstract}

Keywords Women entrepreneurs, Identity work, Interactions, Multiple identities, Case study, Narrative analysis, Biographical interview, Dynamic perspective

Paper type Research paper

\section{Introduction}

Studies on women entrepreneurship have recently received new impetus from identity theory. By drawing on this theory, the concept of identity work has been particularly fruitful to highlight a woman's need to actively overcome major obstacles to build on a credible identity as an entrepreneur and claim legitimacy in a masculinized context (Alsos et al., 2016; Sveningsson and Alvesson, 2003; Watson, 2008). Obstacles are mainly due to potential inconsistencies and conflicts between being women and entrepreneurs (Byrne et al., 2019;

(C) Francesca Maria Cesaroni, Annalisa Sentuti and Maria Gabriella Pediconi. Published by Emerald Publishing Limited. This article is published under the Creative Commons Attribution (CC BY 4.0) licence. Anyone may reproduce, distribute, translate and create derivative works of this article (for both commercial and non-commercial purposes), subject to full attribution to the original publication and authors. The full terms of this licence may be seen at http://creativecommons.org/licences/by/4.0/ legalcode

Funding: This research received no specific grant from any funding agency in the public, commercial or not-for-profit sectors.

The authors would like to thank the anonymous referees for their insightful feedback and useful suggestions.

Declaration of conflicting interests: The authors declare that there is no conflict of interest.
Received 24 April 2020 Revised 26 October 2020 4 February 2021

Accepted 8 March 2021 
IJEBR

27,4

1034
Chasserio et al., 2014; Swail and Marlow, 2018). As many women entrepreneurship scholars have noted, entrepreneurship has been traditionally associated with a masculine discourse (Ahl, 2006; Lewis, 2006), meaning that, compared to their male colleagues, women have to face additional difficulties in constructing their entrepreneurial identity. Many scholars have recently explored how women entrepreneurs manage multiple identities (mother, wife, daughter, sister) and navigate through often conflicting demands and expectations from their different social groups (Chasserio et al., 2014). In these studies, women in different social contexts (Bjursell and Melin, 2011; Essers and Benschop, 2007; Hytti et al., 2017; Welter and Smallbone, 2010) and different stages of their business life cycles and entrepreneurial career (Chasserio et al., 2014; Díaz García and Welter, 2013; Fernandes and Mota-Ribeiro, 2017; Swail and Marlow, 2018) have been investigated.

Results from these studies show that a woman's multiple identities can interact very differently and give rise to adverse and positive interactions (Chasserio et al., 2014; Díaz García and Welter, 2013; Essers and Benschop, 2007). In such analysis, a static approach has been mostly adopted, and women entrepreneurs at a specific time in their entrepreneurial careers have mainly been observed. However, identity studies show that identities are dynamic and change over time (Watson, 2008). Therefore, a dynamic perspective of analysis would be more advantageous and helpful to understand how women's identity work evolves. A dynamic perspective has been adopted by some scholars (Stirzaker and Sitko, 2019), who have investigated how women renegotiate interplays among their multiple identities to accommodate emerging social pressures, personal needs and expectations. However, how interactions among women entrepreneurs' multiple identities evolve throughout their lives, and with which consequences, has not yet been properly investigated, and it remains an overlooked topic in the literature. This article aims to fill this gap by answering the following research question: how do interactions among a woman entrepreneur's multiple identities evolve throughout her life?

To answer this research question, the entrepreneurial experience of an Italian woman who founded a business in the sixties and recently retired after passing it on to her son is described and discussed.

From the methodological point of view, a case study research combined with a narrative approach has been used (Henry et al., 2016; Hytti et al., 2017; Polkinghorne, 1991; Reissman, 2001). This approach has been useful to investigate in-depth the life of a woman entrepreneur who went through all the main phases of an entrepreneurial career, including succession and retirement. Data were collected in the period 2008-2016, combining biographical interviews and follow-up interviews or conversations. Collected data allowed the authors to understand how this woman's experience evolved over time and how she managed the interactions among her multiple identities throughout her life (Henry et al., 2016). Furthermore, since the interviews were carried out when she was in the final phase of her entrepreneurial career, they were also useful in shedding new light on a woman's identity work throughout succession and retirement, which has been largely overlooked in previous studies.

This paper contributes to developing knowledge on women entrepreneurs and identity by revealing that interactions between multiple identities may radically evolve throughout life and that two main processes of change may arise: transformation and fading. Woman's agency proves to be paramount in making these processes possible and helping her achieve personal and professional fulfillment.

This article is organized as follows. The next section presents a brief overview of the literature on women entrepreneurs and identity. The third section describes the methodological approach adopted to collect and analyze data. The fourth section presents the case study, followed by and the fifth section outlines the main findings from the empirical analysis. The sixth section discusses the findings and highlights their contribution to advancing knowledge on women entrepreneurs and identity. The paper ends with the main limitations and possible avenues for future research. 


\section{Literature review}

Women who engage in entrepreneurial activities have to manage the conflict between being a woman and an entrepreneur precisely because, in the collective consciousness, entrepreneurs have been traditionally described as stereotypical males. Therefore, a woman entrepreneur has to engage in identity work to manage the contradictions between gender and entrepreneurship, positioning herself as a woman in entrepreneurial practices and an entrepreneur in gender practices (Bruni et al., 2004a, 2004b).

Scholars use the concept of identity work to refer to the dynamic and ongoing process of identity construction carried out by an agent, through an active negotiation between themselves and constraints existing in social contexts in which they act (Watson, 2008; Hytti et al., 2017; Sveningsson and Alvesson, 2003). Identity work means that human beings continuously engage in forming, repairing, maintaining, strengthening or revising their constructions of self (Sveningsson and Alvesson, 2003) to meet the demands of various social roles or, sometimes, to redefine roles preserving and enact valued aspects of an existing role identity (Nicholson, 1984). The concept of agency is central in this regard as individuals are considered active subjects, who are constantly engaged in "creating a sense of self" (Sveningsson and Alvesson, 2003). Thus, identities are the result of both self-determination and external constraints, norms and expectations (Watson, 2008).

Identity work issues are particularly challenging for all those (men and women) who take on leadership roles (Watson, 2008), but they become especially crucial when applied to women entrepreneurs due to a stereotypical masculinized view of entrepreneur (Chasserio et al., 2014; Díaz-García and Welter, 2013; Hytti et al., 2017; Swail and Marlow, 2018). Indeed, while men can benefit from the alignment between the entrepreneurial discourse masculinized - and their gender identity - masculinity - women entrepreneurs do not have this "advantage of fit" (Swail and Marlow, 2018, p. 24). Consequently, they must engage in a harsh identity work to construct their entrepreneurial identities, their way of seeing themselves as entrepreneurs, as well as to be legitimized as entrepreneurs by others.

From this perspective, several authors have pointed out that many women entrepreneurs choose to conform to the male model and hide their femininity, accepting social norms and expectations without questioning them (e.g. Lewis, 2006). Conversely, other women entrepreneurs question, challenge and reject the masculine norms of entrepreneurship (Díaz-García and Welter, 2013). They pursue authenticity and "self-consciously adopt what is for them an appropriately feminized entrepreneurial identity as a means of being "who I really am" in a business context" (Lewis, 2013, p. 253). Using post-feminism as a critical concept, Lewis (2014) has further developed the idea that women - as well as men - are free to choose, create and express their entrepreneurial identities. She has identified four possible "entrepreneurial femininities" - individualized, maternal, relational and excessive - resulting from how women entrepreneurs construct their subjectivities and what kind of entrepreneur they want to be. Thus, women entrepreneurs' engagement in identity work can produce very different results. While some women entrepreneurs embrace masculinity, other women invent new ways of being an entrepreneur (Díaz-García and Welter, 2013).

Similar results are provided by considering women in family firms (Bjursell and Melin, 2011; Fernandes and Mota-Ribeiro, 2017; Hytti et al., 2017). In these studies, daughters involved in a succession process are mainly investigated. In this regard, Hytti et al. (2017) have suggested that daughters construct and negotiate their identities as family business leaders "in their interactions with others by opposing, expanding, and making use of the gendered scripts available to them. They move between concealing their leader identity and producing a masculinized identity as a strong owner" (p. 681).

Other scholars have broadened the analysis of women entrepreneurs' identity work to take into account that they often play multiple roles and simultaneously operate in different social groups (e.g. business and family) (Chasserio et al., 2014). Thus, they have to manage
Fading and transformation 
IJEBR

27,4

1036

multiple identities because while they are entrepreneurs, they are also mothers, wives, daughters, sisters, etc. Therefore, they are forced to deal with very different and often conflicting norms and demands (e.g. business commitments and family constraints and duties). To manage such conflicts, women entrepreneurs used various daily coping strategies ranging from "accepting conventional norms and social expectations and integrating them in self-identity, or challenging them by accommodation or transformation, or, in turn, by redefining and proposing new norms" (Chasserio et al., 2014, p. 145).

Some authors also observe that different interactions among women's multiple identities may arise (Chasserio et al., 2014; Swail and Marlow, 2018; Stirzaker and Sitko, 2019). Analyses have revealed that conflicting interplays often prevail and result from difficulties in managing demands and expectations associated with various identities. For instance, Swail and Marlow (2018), who interviewed some women founders of emerging ventures, have highlighted contradictions and tensions between feminine identities such as "wife" and "mother" and the stereotypical entrepreneur identity. Specifically, women entrepreneurs with child care responsibilities fight to find a balance between being a mother and a credible entrepreneur. In some cases, they have accepted that they must delay their start-up activities. In other cases, they have expressed the difficulties in managing their multiple identities. Sometimes they have to "attenuate the feminine" (Swail and Marlow, 2018, p. 256), avoiding discussions about symbols of feminine responsibility (such as child care) because they are not accepted in a male entrepreneurial context. Hence, authors have argued that the mother identity can impede their entrepreneurial identity and negatively impact their nascent ventures.

However, opportunities deriving from overlapping identities (e.g. being a mother and entrepreneur) have also been identified, showing that positive interplays are possible when identities enrich each other, producing advantages at the individual or business level (Greenhaus and Powell, 2006, 2011; Leung, 2011; Chasserio et al., 2014). Stirzaker and Sitko (2019) have proven this is especially true for older $(50+)$ women entrepreneurs. Their findings have shown that overlaps among women entrepreneurs' multiple identities produce positive results and enhance their lives with beneficial effects. The authors have observed a synergy between the intersection of older women entrepreneurs' social identities - daughter, mother, wife or grandmother - and their entrepreneurial identity. For instance, a synergy between daughter and entrepreneur identities may emerge because, thanks to the flexibility of their entrepreneurial activities, some women take care of their mothers or, conversely, their mothers take care of their children. However, authors have highlighted that this synergy was deeply influenced by context and the women's life stage.

Some authors have pointed out that entrepreneurial identity construction is a "dynamic process consisting of continuous and simultaneous interactions with other social identities" (Chasserio et al., 2014, p. 129). However, existing studies mainly observe women entrepreneurs in specific phases of their entrepreneurial careers: start-up (Swail and Marlow, 2018); business creation and management (Chasserio et al., 2014; Díaz García and Welter, 2013; Fernandes and Mota-Ribeiro, 2017; Stirzaker and Sitko, 2019); taking over the leadership in family firms (Bjursell and Melin, 2011; Hytti et al., 2017) and the temporal dimension of identity construction processes has been largely neglected. As a result, little is known about how interactions develop overtime, that is, how interactions among multiple identities may evolve throughout a woman entrepreneur's life. This is why some authors have called for further research on this subject (Chasserio et al., 2014), and the adoption of a longitudinal perspective has been encouraged (Díaz García and Welter, 2013).

This paper responds to this call. The authors' assumption is that including the temporal dimension in the analysis of relationships among multiple identities is important because investigations on single phases do not explore what may happen in later phases and how relationships may change over time. This article presents and discusses a woman entrepreneur's life experience to explore interactions among her multiple identities and 
how they evolved throughout her entire entrepreneurial career. In doing so, the analysis also provides new knowledge about the identity work of a woman entrepreneur who acts as an incumbent in a succession process, a topic that has been little investigated so far.
Fading and transformation

\section{Methodology}

A qualitative approach that combines case study research and narrative analysis has been adopted. Both methods are considered particularly appropriate for analyzing women entrepreneurs' stories thoroughly, paying attention to the meaning women give to their experiences in the contexts they live and act in (Henry et al., 2016).

Specifically, a single case study (Yin, 2003; Eisenhardt and Graebner, 2007; Miles et al., 2014) was chosen by the authors because it was deemed suitable for the aim of the research. Indeed, single-case studies help the researchers richly describe a phenomenon and get a deeper understanding of how the phenomenon may evolve over time (Siggelkow, 2007). In single-case research design, cases are chosen because they are unusually revelatory, extreme or rare (Yin, 2003), useful for the investigation of a "transparently observable" phenomenon (Eisenhardt, 1989, p. 537) and particularly suitable for gaining new theoretical insights (Eisenhardt and Graebner, 2007). Moreover, a single case allows for a longitudinal approach, which studies the same case "at two or more different points in time" (Yin, 2003, p. 42). Finally, single-case studies were also specifically used in research on women entrepreneurs to analyze, for instance, how a female entrepreneur enacts leadership over time and how a leader identity can be integrated into an entrepreneurial identity (Lewis, 2015) or to introduce exemplary cases of businesswomen (Bellucci et al., 2016).

At the same time, narrative analysis is considered worthwhile when investigating the process of identity work (Ahl, 2006; Chasserio et al., 2014; Díaz García and Welter, 2013; Lewis, 2015; Hytti et al., 2017; Karhunen et al., 2017; Ozasir Kacar and Essers, 2019). Namely, narratives describe personal experiences and life events and give voice to individual perceptions and interpretations of such experiences and events (Polkinghorne, 1991; Reissman, 2001), representing the means through which an identity is expressed and takes shape (Hamilton, 2014; Polkinghorne, 1991).

In line with the research objectives, the authors referred to their personal contacts and networks to find experienced women entrepreneurs who had also gone through a succession process. However, in Italy, women entrepreneurship is a relatively recent phenomenon, so it was challenging to find women-founded companies that had already undergone a succession process. Simultaneously, Italy is an ideal setting for deepening knowledge on women entrepreneurs' identity work because, among Organisation for Economic Co-operation and Development (OECD) countries, its cultural context has historically been and is still characterized by a very traditional view of women and gender roles and expectations (Alesina and Giuliano, 2010; Cesaroni and Paoloni, 2016; Colombo and Salmieri, 2020; ISTAT, 2016; Lomazzi, 2017). For that reason, the chosen case can be considered quite rare and unusually revelatory. It involves an Italian woman - Vittoria - who founded a business in the sixties and retired a few years ago, after passing the company on to her son Alessandro.

Data were collected from 2008 to 2016, combining two different methods: a biographical interview and follow-up interviews or conversations. In 2008, a biographical interview (Karhunen et al., 2017; Rosenthal, 1993; Wagner and Wodak, 2006) was conducted with Vittoria to reconstruct her life story. The aim of a biographical approach is "to encompass the total life of an individual" or, in other words, allow a person to reconstruct the past and make "decisions as to which individual experiences are relevant, which should or may be included and which he or she would rather omit" (Rosenthal, 1993, p. 3). In a biographical interview, the respondent chooses the course of the interview, while the interviewer ensures that themes relevant to the research have been covered and, if necessary, propose specific questions 
IJEBR

27,4

(Karhunen et al., 2017). It is a largely unstructured interview, and the narrative approach is the most used method to collect biographical information (Wagner and Wodak, 2006). When Vittoria was interviewed in 2008, she was 67 years old. She had been running the business for 43 years, and the succession process was underway. The interview covered four main areas: (1) Vittoria's decision to become an entrepreneur and her entrepreneurial career; (2) business creation and growth; (3) succession and mother-son relationship; (4) current situation of the company and current role of the founder. The authors encouraged an open, flexible and informal dialogue to allow the interviewee to openly describe herself, choose which events to recount and spontaneously give meaning to her experience (Pettigrew, 1997). The interview took place at the company site and lasted $4 \mathrm{~h}$; it was recorded and later transcribed verbatim.

It is important to note that when individuals reconstruct their life story retrospectively, their current perspective determines what events, actions and prior experiences are biographically relevant (Rosenthal, 1993). Thus, the present perspective defines how an individual "develops thematic and temporal links between his or her various experiences and how past, present or anticipated future realities influence his or her personal interpretation of the meaning of his or her life" (Rosenthal, 1993, p. 3). Accordingly, Vittoria's autobiography, carried out during the succession process, was the perfect occasion for her to review her past, interpreting and reinterpreting (Jones et al., 2008) the positive and negative experiences she had had throughout her entrepreneurial career in the light of her current role as incumbent.

The second phase of data collection took place from 2008 to 2016 . After the first in-depth interview, the authors remained in contact with Vittoria. They conducted two brief and informal follow-up interviews (15-20 minutes), exchanged some emails and had at least one telephone conversation per year within the eight-year study period to know how Vittoria's entrepreneurial experience and the succession process were going. She was formally interviewed again in 2016. At that time, Vittoria had already retired, and Alessandro had taken on the leadership role. The last interview took place at the company site, lasted about $2 \mathrm{~h}$, was recorded and later transcribed verbatim. Also, in this case, the interview was mainly unstructured. It focused on the last years of the interviewee's entrepreneurial career, how her career in the company ended and how the mother-son and incumbent-successor relationships evolved accordingly.

To further our understanding and knowledge of the case (Byrne et al., 2021) and enable triangulation (Miles et al., 2014), the interview data were supplemented with other sources including business documentation and website, newspaper articles and online news and two semistructured interviews with the successor as well as field notes from company visits to recorder Vittoria's attitudes and behaviors and the business context. These secondary data helped us contextualize Vittoria's life story and experiences and thoroughly describe the case (Siggelkow, 2007). Thus, combining narrative analysis with the case study made it possible to enrich this investigation. The first one allowed the authors to follow the evolution of Vittoria's identity work, while the latter was useful for clearly defining the context of her experience (Hytti et al., 2017).

The data analysis took place in several phases and was conducted inductively (Hytti et al., 2017). Thus, the authors read and reread all the interviews to familiarize themselves with Vittoria's experience, and sections dealing with the research objectives were noted. Particular attention was paid to how Vittoria talked about herself, her relationships with others, the events she decided to recount and the meaning she gave to such events (Hamilton, 2014; Hytti et al., 2017). Subsequently, a detailed and comprehensive case description was built up, combining information from the different sources to create an overview of the case and Vittoria's life story (see section 4). Next, narratives were reread and then iteratively and inductively analyzed with a narrative analysis (Hytti et al., 2017). The authors looked at passages in which the interviewee referred to her identities and how they interacted during her entrepreneurial career. They also explored how Vittoria managed her multiple identities and were particularly interested in how she reconciled the different demands of various domains throughout her life. Finally, a dynamic perspective was adopted to explore "if and eventually 
how" (Poggesi et al., 2016, p. 756) the entrepreneur had dealt with specific issues differently (e.g. family commitments, the importance of career, etc.) at different life cycle stages. This allowed the authors (1) to identify the main phases of Vittoria's entrepreneurial career, to analyze her identities and main challenges in each phase and how multiple identities interacted during her life (see section 5.1) and (2) to recognize how such interactions evolved throughout her life (see section 5.2). Finally, the theoretical and practical contributions of this study in advancing knowledge on women entrepreneurs and identity work were discussed (see section 6).
Fading and transformation

\section{Case study overview}

Vittoria had dreamed of being an entrepreneur since she was a young girl and worked arduously to achieve her goals. The start-up phase was not straightforward since she had neither money nor experience. Moreover, she had a two-year-old son, named Andrea. Her father loaned her the capital to set up the business guaranteeing his support and their great relationship help her get off to start.

Vittoria was able to found her own company in 1965 . She was very creative and drawn to the fashion world, so she started producing women's clothing. The business grew quickly, achieving terrific results. However, working in a man's world was not easy at all. She had to face many challenges due to the traditionalist mindset prevailing at that time and the deeprooted gender stereotypes.

After the birth of her second child, Alessandro, finding a balance between work and family became a challenge. Vittoria felt pressured by her maternal responsibilities and preferred choosing a less demanding sector instead of delegating the care of her children. Thus, despite her great passion for the fashion world, she decided to start making work clothes for hotels, restaurants, medical laboratories, beauty centers and factories.

By the early seventies, Vittoria was a well-established entrepreneur. The company employed 65 people and produced about 1,200 work clothes a day for very influential customers. The work atmosphere was familiar and characterized by strong commitment, confidence, communication, trust and shared responsibility. Conversely, relationships with suppliers and customers were problematic because they found it difficult to consider her a credible entrepreneur. Nevertheless, she moved ahead and achieved excellent results. In 1989, she received a prestigious national award for being one of the longest-serving Italian woman entrepreneurs. She was also awarded an honorary degree in economics and business and was the only woman on the board of an important business association for over 20 years.

Meanwhile, Vittoria started familiarizing her children with the business. Andrea realized that he did not want to work at the family firm. So, he left the company, and despite her feelings about it, Vittoria accepted his decision. After Alessandro graduated, he studied English abroad and then began working for the business. For two years, he worked in several areas of the company and, during this period, Vittoria transferred her knowledge and experience to Alessandro and encouraged him to study management. Due to their different personalities and viewpoints, conflicts could not be avoided, but Vittoria was able to defuse conflicts, limiting exasperation and negative interactions. When Vittoria realized that Alessandro was ready, she decided to pass on the leadership of the company to him. However, it was not easy as Vittoria was very attached to her company. Their mother-son relationship continued smoothly and was constructive. Even her son described their succession as a "smooth process." Vittoria formally retired from the business in 2011 due to health reasons. Alessandro continued to keep her informed about the business, and she remained his most valuable mentor.

At the end of her entrepreneurial experience, she proudly stated she was fully satisfied with the results: "I am truly satisfied. I feel fulfilled as a mother, an entrepreneur, and a woman." She admitted that being a woman caused her serious problems, but she also acknowledged that she was able to successfully manage them: "I took advantage of being a woman." 
IJEBR

27,4

1040

\section{Findings}

Vittoria's narrative shows that she enacted three main identities that interacted throughout her life: entrepreneur, woman, mother. This is not a surprising result as many other scholars have identified these three identities as those that mainly challenge the identity work of women entrepreneurs (Chasserio et al., 2014; Stirzaker and Sitko, 2019). In previous studies, interactions among these identities have been mainly observed in specific phases of women entrepreneurial careers and how such interactions may change throughout women entrepreneurs' lives and careers is not well known. Thus, in line with the purpose of this study, in this section, Vittoria's narrative is analyzed to understand (1) how her multiple identities interacted in the various phases of her entrepreneurial experience (section 5.1) and (2) how such interactions changed throughout her life and career (section 5.2).

\subsection{Interactions among multiple identities at different stages of a woman's entrepreneurial career}

Vittoria's narrative shows that her identities were subject to constant interaction throughout her entrepreneurial experience. For this reason, we have divided it into three main phases: business creation and growth, business maturity and succession and retirement. Each phase corresponds to a major challenge Vittoria had to face: being considered a credible entrepreneur, passing the business on to her son and leaving the entrepreneurial role. Phases and challenges are summarized in Table 1, where representative quotes from Vittoria's interviews, where she talks about her identities and their interactions are also presented. Finally, in the fourth column, there are labels describing such interactions.

In the first phase of Vittoria's career, managing multiple identities was a major hurdle. When she started her business, she was a young woman and had to contend with the narrow mindedness of that time as being an entrepreneur was considered completely inappropriate for a woman (Cesaroni and Sentuti, 2014): "In the Sixties, women did not even work, especially in a little village with 3,000 people; women stayed at home." Even in the following years, when her company was developing, Vittoria continued to experience serious conflicts between being a woman and an entrepreneur, and she collided even more violently with rooted gender stereotypes: "I had to travel, leave, arrive alone - a woman alone - and people and my relatives always had something to say about it."

From this point of view, being an entrepreneur in a traditionally feminine industry was of no help to her and this result confirms that creative industries such as fashion are "seemingly highly "feminized" but actually, "the same gender-related barriers that exist within other industry sectors are just as prevalent, if not more so, within the creative sector" (Henry, 2009, p. 143). As a consequence, Vittoria struggled to be accepted as an entrepreneur because the accepted wisdom was that a woman could only play minor roles within a company. Vittoria had to be clever and call on her determination not to be overwhelmed by these gender prejudices. And she was very ingenious in inventing a smart trick to deal with a problem she often encountered with customers: "A very funny thing happened, 4-5 years after I had started selling suits and work clothes. Customers [...] would call the company and say: "I'd like to speak to the boss, I need some suits" and I would respond: "I'm the boss." They would say: "You're a woman!" And they would stop talking ... and no one would call me back. One day I had a good idea. They would call me and say: "I need some suits, ma'am" —or rather they called me "miss" - "Can I speak to the boss?" And I would say: "The boss is out, but I'd be happy to help you. I'm the secretary". And they finally told me what they wanted. I did this for 13 years. I was my own secretary for 13 years, and it went so well." Being a woman also created many problems for her at the banks - "Banks were a great problem because they did not trust me"- and caused relational drawbacks with customers and suppliers. As a result, Vittoria always had to be extremely careful and blameless at all times to avoid criticism and 


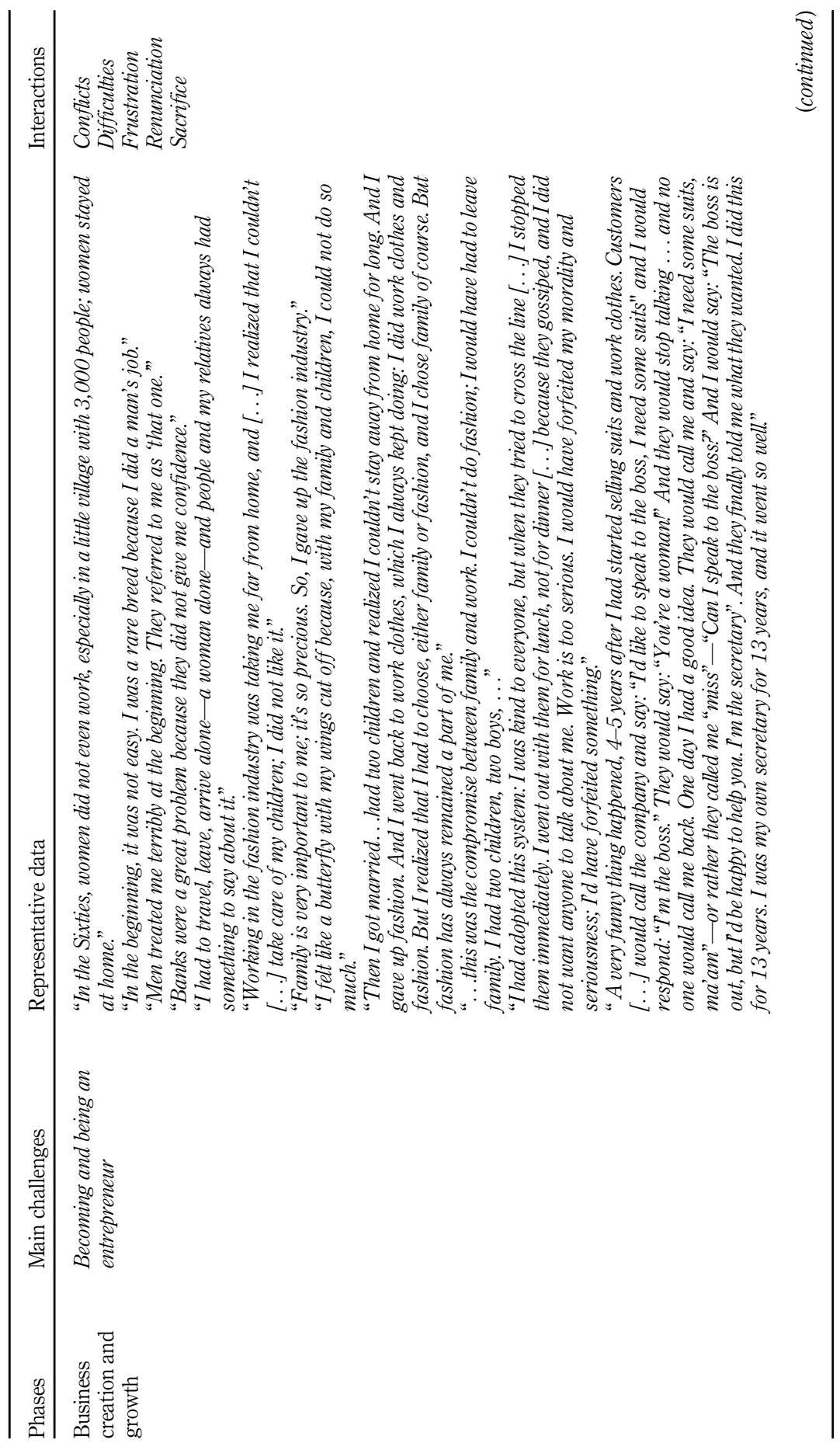

Fading and transformation

Table 1. Interactions among the identities of woman, mother and entrepreneur 
IJEBR
27,4

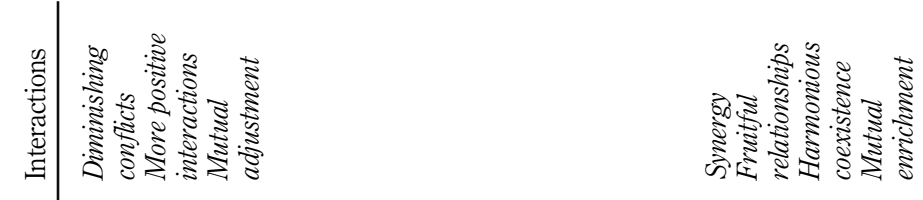

₹

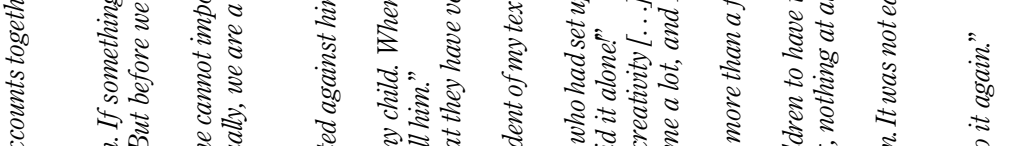

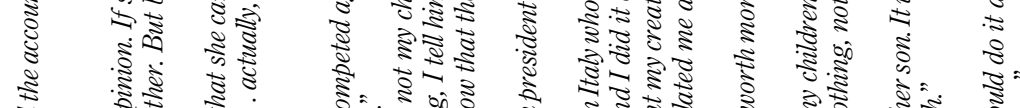

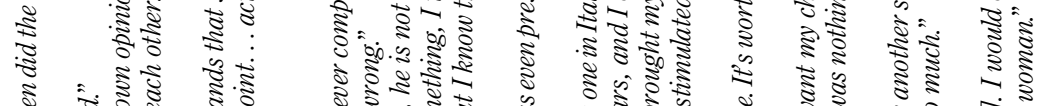

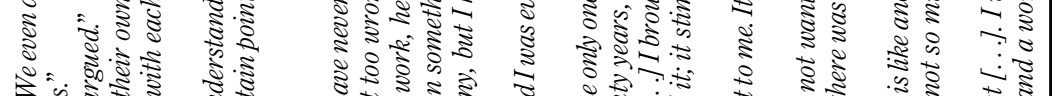

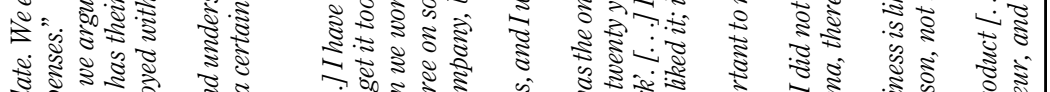

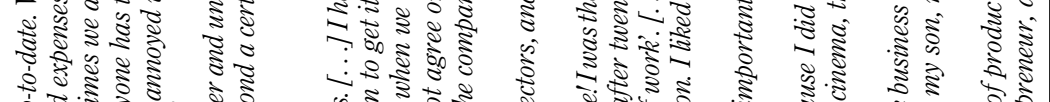

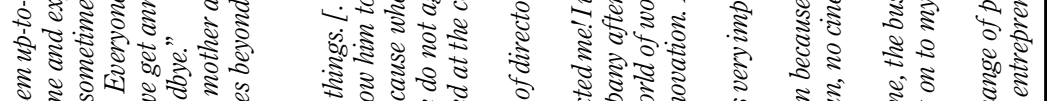

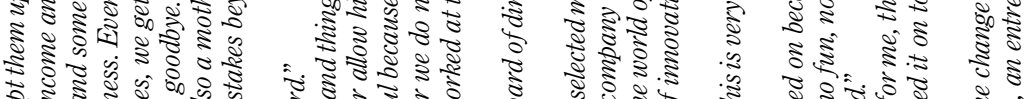

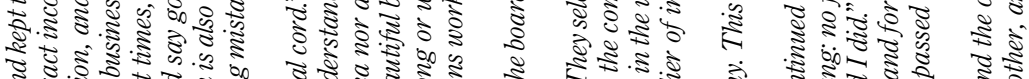

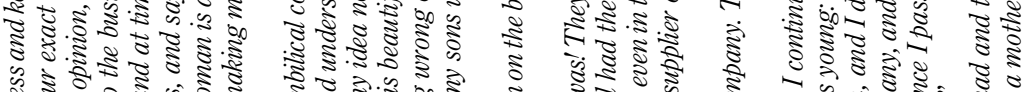

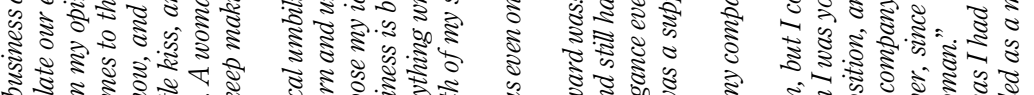

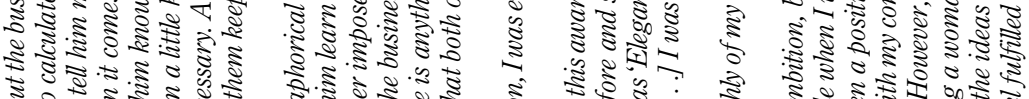

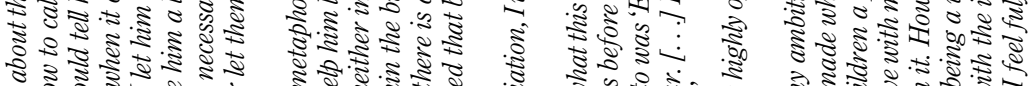

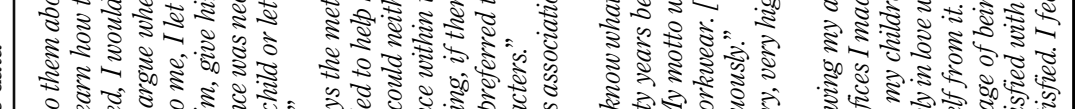

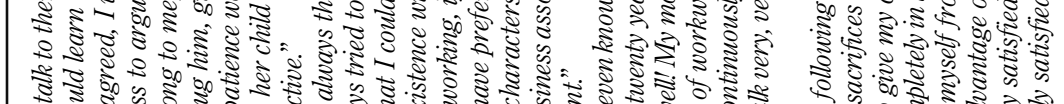

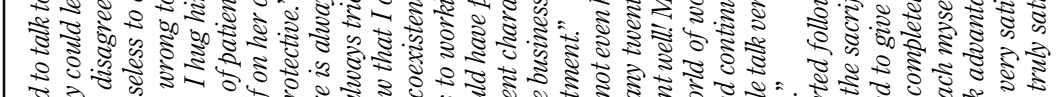

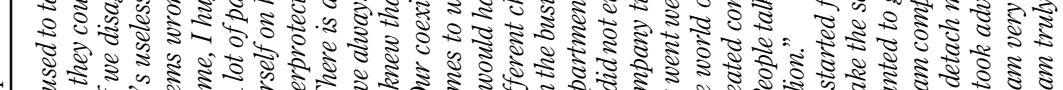

5 की

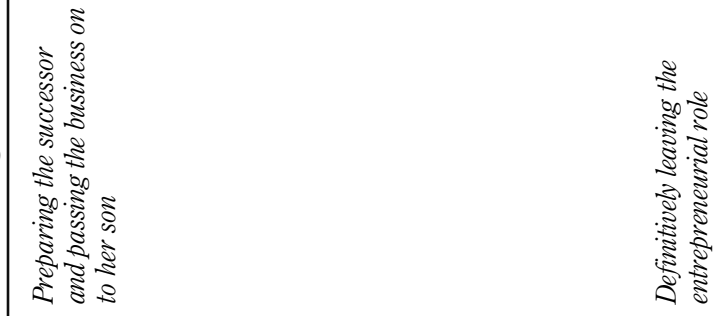

Table 1.

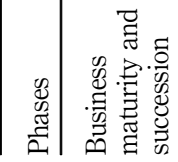

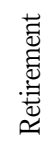


false moves: "I had adopted this system: I was kind to everyone, but when they tried to cross the line [...] I stopped them immediately. I went out with them for lunch, not for dinner [...] because they gossiped, and I did not want anyone to talk about me. Work is too serious. I would have forfeited my morality and seriousness; I'd have forfeited something."

Other conflicts stemmed from the fact that Victoria had two children, so she had to make important decisions, which profoundly affected her entrepreneurial career. She realized that running a company in the fashion industry would be a major hindrance and would prevent her from raising her children properly: "Working in the fashion industry was taking me far from home, and [.. .] I realized that I couldn't [. . .] take care of my children; I did not like it. [.. .] Family is very important to me; it's so precious. So, I gave up the fashion industry." Hence, she decided to prioritize her mother identity and sacrifice her entrepreneurial ambitions, by choosing a less demanding industry - work clothes - to have more free time for her children: "And I went back to work clothes, which I always kept doing: I did work clothes and fashion. But I realized that I had to choose, either family or fashion, and I chose family of course. But fashion has always remained a part of me." Vittoria's decision to downscale her professional ambitions stemmed from the need to rebalance work and family through a compromise that is very common for female entrepreneurs who desire a satisfying working life without penalizing their family (Jennings and McDougald 2007; Cesaroni et al., 2018).

In the next phase - business maturity and succession - conflicts between Vittoria's multiple identities blurred. However, it was challenging for her to manage her children while keeping her identities of mother and entrepreneur separate. For example, as an entrepreneur, she would have liked both sons to work in the company, but as a mother, she accepted Andrea's choice and fully supported him. Vittoria admitted: "I would have preferred that both of my sons worked at the company, but I know that they have very different characters." She was also delighted with Alessandro's decision to join the company and helped him prepare for his future role as leader, gradually imparting her experience and tacit knowledge. During this phase, Vittoria tried to stifle her mother identity: "Our coexistence within the business is beautiful because when we work, he is not my child. When it comes to working, if there is anything wrong or we do not agree on something, I tell him," even though it sometimes inevitably happened because "There is always the metaphorical umbilical cord." Vittoria recalled: "A lot of patience was necessary. A woman is also a mother and understands that she cannot impose herself on her child or let them keep making mistakes beyond a certain point. . . actually, we are a bit overprotective.” Despite this, Vittoria was clever and skillful in avoiding conflicts between being a mother and an entrepreneur. Above all, she taught her son that conflicts were not personal issues but an opportunity to learn: "I've always tried to help him learn and understand things [...] I've never competed against him." In the meantime, Vittoria's company had grown, and she had gained the trust of many customers who appreciated her products and considered her a serious and talented businesswoman. Vittoria also derived important acknowledgments from her work that rewarded her entrepreneurial skills and her commitment to her business career. At the same time, they demonstrate Vittoria's ability to overcome most of the problems she faced at the beginning of her career and to reconcile her identities as a woman and as an entrepreneur.

In the last phase, Vittoria retired, even though she never gave up her entrepreneurial identity: "I am completely in love with my company, and for me, the business is like another son. It has not been easy to detach myself from it. However, since I passed it on to my son, not so much." She became the most trusted advisor to her successor and allowed him to benefit from her long experience. So, at the end of her entrepreneurial experience, her goals as a mother and as an entrepreneur had been achieved, and she proudly could state, "I started following my ambition, but I continued on because I did not want my children to have to make the sacrifices I made when I was young: no fun, no cinema, there was nothing, nothing at all. I wanted to give my children a position, and I did."
Fading and transformation 
IJEBR 27,4

\section{4}

\subsection{The evolution of multiple identities' interactions throughout a woman entrepreneur's life and career}

Vittoria's narrative describes the story of a woman who conducted a long journey through entrepreneurship, facing gender stereotypes, conflicts among different identities, difficulties in achieving her goals. However, at the end, she was able to achieve full satisfaction as a woman, entrepreneur and mother. How did adverse interactions at the beginning of her entrepreneurial experience turn into positive interactions, enabling her to attain such results? To answer this question, a dynamic perspective was adopted to explore how interactions among her multiple identities evolved through her entire entrepreneurial life. In this regard, from the analysis of Vittoria's narrative, two main processes of change, which evolved in parallel throughout the life of this woman entrepreneur, were identified: fading and transformation (Figure 1).

The fading process: This process concerns Vittoria's woman and entrepreneur identities and describes how interactions between them evolved throughout Vittoria's life. Her narrative shows that initial conflicts gradually disappeared, leaving room for a harmonious coexistence. Adverse interactions between woman and entrepreneur identities are widely discussed in the literature (Chasserio et al., 2014; Díaz-García and Welter, 2013; Essers and Benschop, 2007; Swail and Marlow, 2018) and were also observed in the analyzed case. At the beginning of Vittoria's entrepreneurial experience, being a woman was a strong constraint because it hindered her from being considered a credible entrepreneur. Except for her father and employees, everyone (relatives, suppliers, customers) only saw her woman identity and considered it in deep conflict with her entrepreneurial career. During the interview, Vittoria very clearly described the difficulties of the early days: "In the beginning, it wasn't easy. I was a rare breed because I did a man's job. [...] Men treated me terribly at the beginning. They

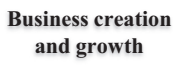

Business maturity and succession
Retirement

Interactions between mother and entrepreneur identities

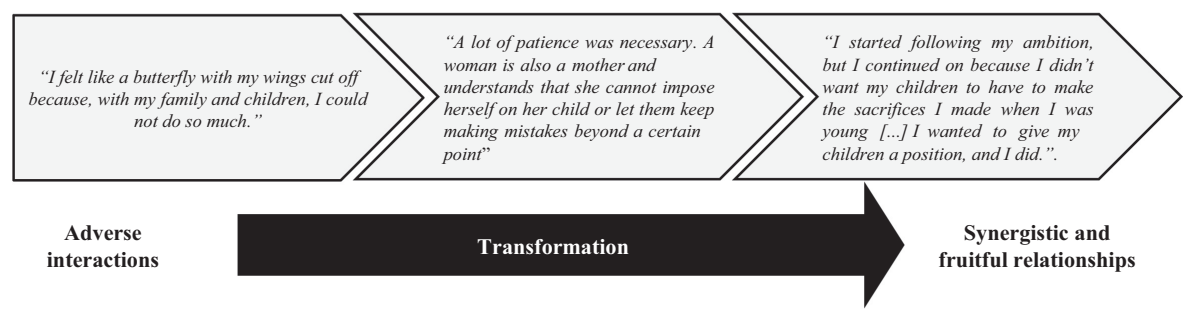

Interactions between woman and entrepreneur identities

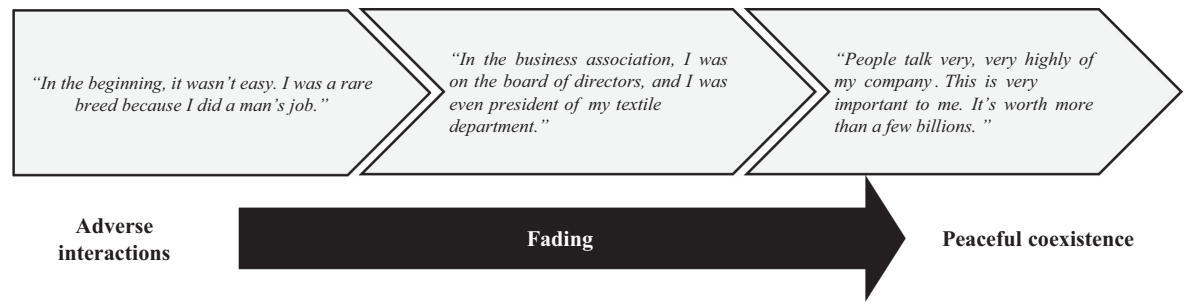

Figure 1. Interactions among multiple identities over time 
referred to me as 'that one'." For these reasons, Vittoria sometimes had to cloak her woman identity and be very shrewd in dealing with the men she met for business. With them, she was forced to establish clear rules and boundaries, to prevent them from misinterpreting her kindness and her friendly disposition. On the contrary, Vittoria was sometimes forced to hide her identity as an entrepreneur, especially when dealing with customers. In this regard, the anecdote described during the interview - when she had the idea of pretending to be the secretary - is emblematic, precisely because it shows how difficult it was for her to be taken seriously, equal to a man.

Despite these difficulties, Vittoria never renounced any of her identities, even though she sometimes had to accept that she could not be completely herself. She always defended her desire to be an entrepreneur and never resigned herself to considering being a woman as an obstacle. Her perseverance and determination were later rewarded by the reputation she earned as a great innovator and talented entrepreneur and her company's success and the esteem in which her company was held: "People talk very, very highly of my company. This is very important to me. It's worth more than a few billion."

Vittoria always held the reins of her life. Her self-esteem and positive approach were crucial. She never suffered gender stereotypes or fell victim to them; she never gave up on her goals and always found the right compromise between different conflicting demands and expectations. She was a woman who creatively and shrewdly leveraged her resources (selfesteem, creativity, determination, etc.) and found a way to neutralize gender stereotypes progressively, without openly fighting them. Vittoria bucked social conventions by pretending to observe them to achieve her goals. Sources of conflict at the beginning evolved positively. The contrast between her woman and entrepreneur identities progressively disappeared, giving way to a harmonious and peaceful coexistence between them. In other words, the adverse interactions of the early years faded away, and her identities stopped hindering each other. Therefore, Vittoria held onto being a woman and embraced femininity in doing business and entrepreneurship (Lewis, 2014) successfully.

The transformation process: The second process of change concerns adverse interactions between mother and entrepreneur identities that turned into synergistic and fruitful relationships. As is common for many women entrepreneurs whose career cycles coincide with their biological cycles, being a mother was a hindrance to starting and running the business (Jennings and McDougald, 2007). Throughout Vittoria's life, in fact, both the business and the family were growing simultaneously. So, the need to choose between being a "good" mother or a "good" entrepreneur arose: "I felt like a butterfly with my wings cut off because, with my family and children, I could not do so much." Vittoria faced the problem with a determination not to cede ground (maintaining both identities), creativity and self-awareness. She revised her own expectations by abandoning the fashion world to take care of her children and downplaying her entrepreneurial identity to meet her mother identity's needs: "... this was the compromise between family and work. I couldn't do fashion, I would have had to leave family. I had two children, two boys. .." She also protected her entrepreneurial identity by transferring her creativity, sensitivity and passion to the new business. She brought innovation to the work wear industry and implemented a clear differentiation strategy. This led the company to be enormously successful and, in turn, bolstered Vittoria's entrepreneurial identity: "It went well! My motto was 'Elegance even in the world of work'. [...] I brought my creativity [...] to the world of workwear. [.. .] I was a supplier of innovation. I liked it; it stimulated me a lot, and I created continuously. What seemed like a constraint (being a mother) turned into an opportunity and a resource for the entrepreneur: while in the fashion industry, she probably would have been "one of many," in the work wear industry, she created a new trend and her company was very successful.

Over time, interactions between her mother and entrepreneur identities became even more evident. In running the business, Vittoria took advantage of being a mother to create a
Fading and transformation 
IJEBR

27,4

1046

pleasant and familiar working atmosphere for her employees, considered as family members. Later on, Vittoria used the sensitivity and empathy of her mother's identity to prepare and successfully manage the succession process: "It's useless to argue when it comes to the business. Everyone has their own opinion. If something seems wrong to me, I let him know, and at times, we get annoyed with each other. But before we go home, I hug him, give him a little kiss, and say goodbye." In this phase of her entrepreneurial career, the identities of mother and entrepreneur were no longer in conflict. Contrarily, they enriched each other, generating mutual advantages, thanks to how she had managed them in the previous phases. Ever since her children were young, Vittoria had tried to pass down her passion for business to them and groom them as potential successors: "I used to talk to them about the business and kept them up-to-date. We even did the accounts together, so they could learn how to calculate our exact income and expenses." This is in line with the traditional role of mothers in family firms where they have usually been described as "emotional leaders" that is key but invisible actors in transmitting family and business values to the children, teaching them "to love the company" (Jimenez, 2009, p. 55). Vittoria was able to adopt a maternal approach in her role of incumbent entrepreneur, showing fine sensitivity, attention to the mother-child relationships and great communication abilities. She was able to timely and befittingly use her mother and entrepreneur-incumbent identities, emphasizing and downplaying one or the other depending on the situation. For instance, she acted as an incumbent during discussions about the business: "If we disagreed, I would tell him my opinion, and sometimes we argued." However, being a mother helped her solve conflicts and manage the family succession successfully: "You know that you can neither impose your idea nor allow him to get it too wrong." Thus, Vittoria managed the transition so that it took place without traumas both for the family and the business. At the end of her entrepreneurial experience, Vittoria's mother identity benefited from her entrepreneurial one, allowing her to better support and advise Alessandro. Being an entrepreneur turned into an opportunity and a resource for her role as a mother; therefore, the interaction between Vittoria's mother and entrepreneur identities evolved significantly throughout her life. The adverse interactions turned into synergistic and fruitful relationships and produced advantages on a personal (fulfillment as mother and entrepreneur) and business level (successful succession). She did not hide that leaving the fashion world was a great sacrifice, but she also recognized that the decision proved to be a winning one and opened the door to new business opportunities: "I am very satisfied, with the ideas I had and the change of product [. . .]. I would do it again." For this reason, at the end of her career, she was proud to declare her full satisfaction " $a$ s a mother, an entrepreneur, and a woman."

The key role of the agent: In Vittoria's experience, fading and transformation were not spontaneous processes of evolution caused only by the change of contextual factors over time (e.g. age of children or change of cultural models). The identity work of the agent through her lifetime was a decisive factor (Watson, 2008). Vittoria was able to embrace and exploit her multiple identities to make the most of each one over time. Although adverse interactions arose at the beginning, she always maintained and protected her woman, mother and entrepreneur identities because they made her feel fulfilled. She never renounced any of them and no single one was ever allowed to overwhelm the others in the long term. Vittoria deemed them all essential for defining who she was and, above all, who she wanted to be. She saw them all as key parts of herself, integral to living authentically and coherently with her ambitions and goals.

This attitude (i.e. the willingness not to give up any of her identities) proved beneficial in the long term because otherwise she would have had to give up a part of herself. Moreover, perhaps, focusing only on being an entrepreneur, or a mother, would have had negative effects on this woman entrepreneur's life. For example, she could have decided to conform to the male model of entrepreneurship and hide her femininity (Lewis, 2014). Moreover, devoting 
her life exclusively to the business could have undermined her relationship with her sons and made it difficult to recover that relationship later on (Kaslow, 1998). Conversely, dedicating her full attention and effort to the family would have prevented her from becoming a successful entrepreneur. Finally, managing family succession only by enacting the identity of mother could have challenged the business's viability as using merely the entrepreneurincumbent identity could have damaged her and her son's relationship.

In conclusion, the fading and transformation processes were the result of Vittoria's ability to find a balance between her identities by cleverly varying the strength, visibility or intensity of each. Vittoria was able to emphasize or downplay her identities depending on the circumstances, modulating them to obtain effective interactions throughout her life. This helped her live out and conclude her entrepreneurial experience with full gratification and fulfillment in each domain she considered important.

\section{Discussion}

This paper focuses on women entrepreneurs' multiple identities and explores how they may interact throughout the life of a woman entrepreneur. Previous studies have analyzed possible interactions between multiple identities, underlying both conflicting and positive relationships (Chasserio et al., 2014; Díaz-García and Welter, 2013; Essers and Benschop, 2007; Leung, 2011; Stirzaker and Sitko, 2019; Swail and Marlow, 2018). However, they focused on a specific phase of women's entrepreneurial career and did not consider how interactions may evolve in the long run. Since identities are dynamic and can change over time (Watson, 2008), some authors have conjectured that interactions may also evolve and have called for further research on this subject (Chasserio et al., 2014). This paper responds to the call and provides four theoretical contributions.

First, findings reveal that interactions may radically evolve throughout a woman entrepreneur's life, and two main processes of change may arise: transformation and fading (Figure 2). In the transformation process, adverse interactions between identities turn into synergistic and fruitful relationships for a woman entrepreneur. In the fading process, conflicts between identities gradually disappear, giving way to peaceful coexistence. This result deepens our understanding of interactions. It not only confirms that interactions may evolve throughout the life of a woman entrepreneur, but it also shows what processes of change these interactions may undergo and how crucial is the role of the agent. Chasserio et al. (2014) had already postulated that an adverse interaction at a particular moment in a woman entrepreneur's life might later become more positive. This study empirically confirms their assumption and adds an explanation as to how this may happen.

Second, methodologically, this paper points out the relevance of a dynamic perspective in analyzing interactions between multiple identities in the total life of an individual. Previous studies have investigated women entrepreneurs in specific stages of their entrepreneurial experience, and interactions sometimes similar to those described in this paper have been identified. However, these studies adopt a short-term approach (Chasserio et al., 2014; Díaz García and Welter, 2013; Fernandes and Mota-Ribeiro, 2017; Stirzaker and Sitko, 2019; Swail and Marlow, 2018). They do not pay attention to what happens in the subsequent phases and how choices and behaviors of a particular period can affect future events and behaviors in women's lives. This paper goes beyond this approach as it takes on a long-term perspective and shows that interactions among a woman's multiple identities can also undergo drastic changes throughout her lifetime. Moreover, using the biographical interview to reconstruct the woman entrepreneur's life allowed the authors to observe how she recounted her past and how she interpreted and reinterpreted her story (Jones et al., 2008), observing it from the perspective of a woman who has reached the end of her entrepreneurial career. Findings prove that this approach is useful in furthering knowledge on interactions among identities,
Fading and transformation 


\section{IJEBR}

27,4

\section{8}

Figure 2.

The processes of change in interactions among multiple identities

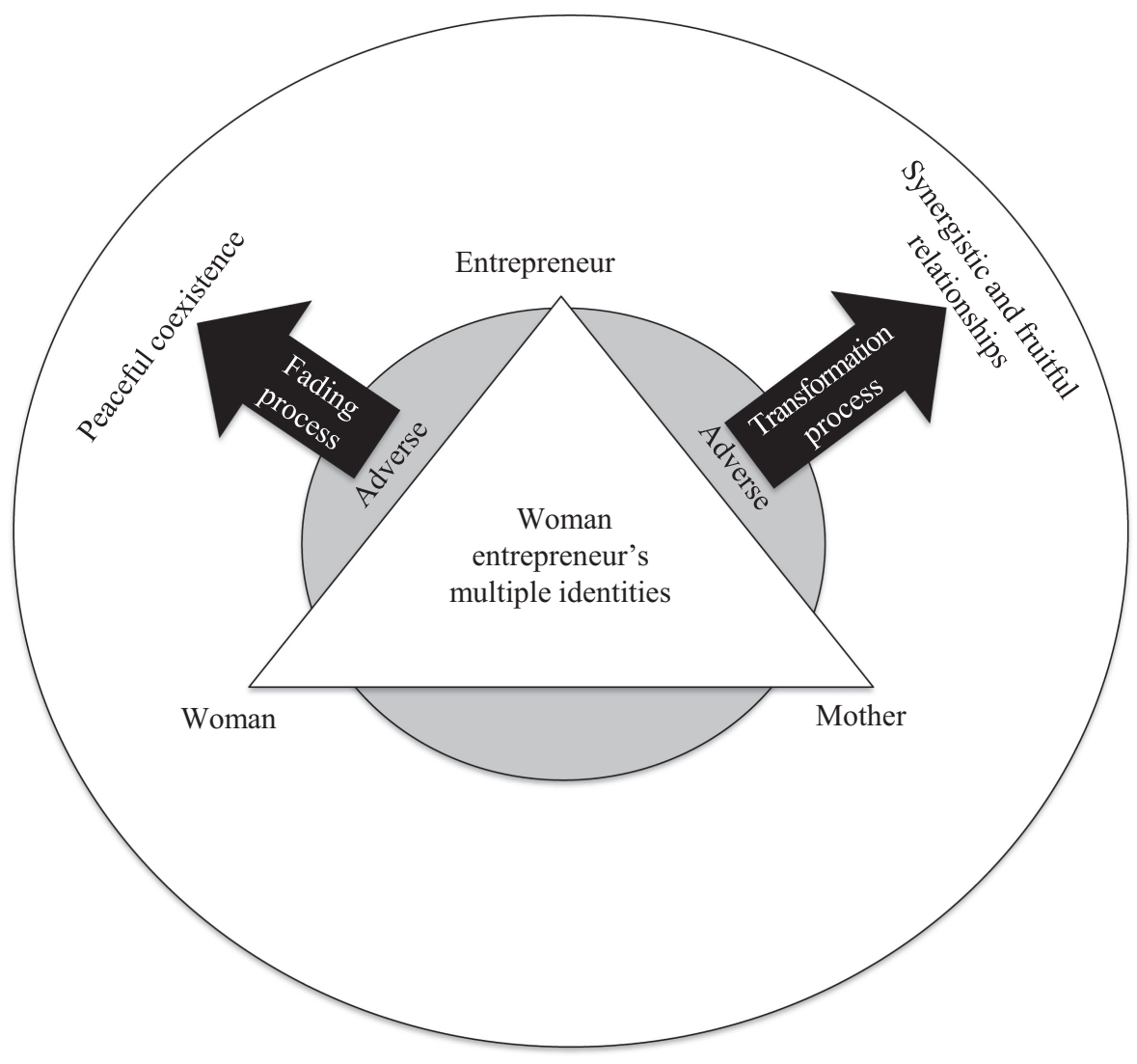

and their possible evolution highlights consequences that would have remained unknown with a short-term approach. For example, if the analysis had stopped at the beginning of the interviewed woman's entrepreneurial career, her narrative probably would have highlighted the classic conflict between being a woman, mother and entrepreneur. The positive evolution of interactions would have been missed out. The adoption of a dynamic perspective allowed the authors to grasp the evolutionary processes of interactions fully, making it possible to highlight that overcoming or eliminating conflicts among multiple identities could sometimes be difficult or impossible in the short term. However, these results can be achieved in the long term, and, sometimes, what is experienced in a certain period of life as a sacrifice or a difficulty, may turn out to be fruitful in later stages of life.

Third, this paper sheds light on the overlooked topic of succession in women-owned family firms. Typically, family business succession unfolds from father to son or (more rarely) to daughter (Jimenez, 2009; Sentuti et al., 2019). Women, especially mothers, have often been described as crucial but invisible actors not directly involved in succession (GillisDonovan and Moynihan-Bradt, 1990), as mediators in managing conflicts between the incumbent and successor (Hollander and Bukowitz, 1990) or as the "emotional leader" responsible for maintaining peace and harmony in the family and the firm and transmitting family and business values to the children (Jimenez, 2009, p. 55). How a woman incumbent copes with her multiple identities in passing on her entrepreneurial role to offspring has 
remained an unanswered question both in entrepreneurship and family business studies. Knowing how a woman entrepreneur experienced succession and retirement, and how the relationship between her multiple identities unfolded, is relevant, considering these phases are characterized by completely different objectives, demands and behaviors. Specifically, the analyzed case shows that succession is particularly challenging in terms of identity work for a woman entrepreneur. It once again calls into question the identities of mother and entrepreneur, but their interactions are very different from that characterizing the early stages of a woman's entrepreneurial experience. Thanks to the inclusion of the succession and retirement phases in the investigation, this paper offers some early results on this subject, suggesting that mother and entrepreneur-incumbent identities are deeply interconnected and can enrich each other throughout the whole process, favoring a successful succession. Findings also show that the positive interaction between mother and entrepreneur identities in the succession process has its roots in behaviors and choices made in previous phases, confirming the usefulness of analyzing the entire life cycle of the woman entrepreneur to capture these dynamics.

Four, findings suggest that women should be active subjects not only in defining their identities (Watson, 2008) but also in orienting interactions toward positive evolutions. The authors recognize the relevance of external factors (Stirzaker and Sitko, 2019), events in different social dimensions (Chasserio et al., 2014) and sociohistorical circumstances (Diaz García and Welter, 2013) in the process of identity construction and interactions; however, this research shows that processes of transformation and fading in interactions among multiple identities do not occur spontaneously as a mere consequence of life events or contextual factors. Women's agency proves to be paramount in making these processes possible and achieving their full personal and professional fulfillment.

In terms of practical implications, experiences such as those described in this article can be useful in fostering a different vision of both women entrepreneurs' multiple identities and entrepreneurship. Many studies have analyzed obstacles that women encounter in doing business due to demands associated with their multiple identities and difficulties in striking a balance between private life, family and business. Consequently, women may be discouraged from starting new businesses because of these challenges. However, this paper shows that conflicting relationships between multiple identities may evolve, encouraging women to enhance their entrepreneurial talents and fulfill their entrepreneurial ambitions. Moreover, even if motherhood has often been viewed as a constraint for women entrepreneurs (Lewis, 2014; Byrne et al., 2019), the case highlights that it can become a factor that favors a woman's creativity and that, over time, can strengthen her entrepreneurial identity. Findings also contribute to increasing women entrepreneurs' self-confidence and self-efficacy. In studies on women entrepreneurship, stories about women's best practices have been strongly encouraged (Díaz García and Welter, 2013) as they are deemed useful in challenging the "masculine norms of entrepreneurship" (Lewis, 2006, p. 453) and the stereotyped masculine profile of an entrepreneur. Such stories help spread and strengthen the idea that entrepreneurial experiences can vary and that it is possible to be a successful entrepreneur in very different ways. This paper lends weight to the idea that there is no single entrepreneur model, and every woman should feel free to define her own way of being an entrepreneur. Spreading this awareness can be very effective in supporting and encouraging women's entrepreneurship, sometimes much more so than training courses that provide knowledge and skills for running a business. To this end, studies like this one can be useful not only in promoting the diffusion of knowledge about women entrepreneurs but also in favoring a change in the standard way of thinking and the cultural context in which women act. Finally, by presenting a case with the dyad mother-son in family business succession, the authors hope to solicit further attention for the role of women within family firms - with attention focused specifically on women as
Fading and transformation 
IJEBR 27,4

incumbents in order to foster a change in the way we habitually consider succession, traditionally conceived as taking place with a father-incumbent.

\section{Conclusions}

This article has investigated how interactions between multiple identities may evolve throughout a woman entrepreneur's life. By combining narrative analysis and case study, two main processes of change were identified: transformation and fading. In this perspective, the paper makes a contribution to insights into women entrepreneurs' identity work, succession process and the role of women entrepreneurs within family firms and has some practical implications for how women entrepreneurship is perceived and promoted.

Nevertheless, although this study has provided a theoretical and practical contribution, the authors are conscious that it presents several limitations. The research was done with a single case study of an Italian woman. The authors recognize the need to embark on comparative studies with different women entrepreneurs within the same cultural context and within different contexts in order to investigate intergroup differences as regards personal experiences and contextual factors. Fruitful future research could focus on women entrepreneurs-incumbents. As the number of companies founded and led by women is rapidly growing in many countries, succession from mother to offspring is becoming an extremely relevant topic and should also be considered an important direction for future research (Sentuti et al., 2019) in the field of entrepreneurial identity studies. Finally, two possible processes of change in the interaction among multiple identities were identified. Further investigations are needed to explore other possible processes of change in the vast and heterogeneous world of women entrepreneurs.

\section{References}

Ahl, H. (2006), "Why research on women entrepreneurs needs new directions", Entrepreneurship Theory and Practice, Vol. 30 No. 5, pp. 595-621.

Alesina, A. and Giuliano, P. (2010), "The power of the family", Journal of Economic Growth, Vol. 15 No. 2, pp. 93-125.

Alsos, G.A., Clausen, T.H., Hytti, U. and Solvoll, S. (2016), "Entrepreneurs' social identity and the preference of causal and effectual behaviours in start-up processes", Entrepreneurship and Regional Development, Vol. 28 Nos 3-4, pp. 234-258.

Bellucci, A., Mari, L.M. and Picciaia, F. (2016), "The her story of the Società Anonima per Azioni Perugina: the role of Luisa Spagnoli in the development of the Italian chocolate industry in the first 30 Years of the twentieth century", in Sargiacomo, M., D'Amico, L. and Di Pietra, R. (Eds), Accounting and Food: Some Italian Experiences, Routledge, New York, pp. 190-209.

Bjursell, C. and Melin, L. (2011), "Sweden: two-fold succession in a family business matriarchy: a Swedish case", in Halkias, D., Thurman, P.W., Smith, C. and Nason, R.S. (Eds), Father-daughter Succession in Family Business: A Cross-Cultural Perspective, Gower, Surrey, pp. 183-192.

Bruni, A., Gherardi, S. and Poggio, B. (2004a), "Entrepreneur-mentality, gender and the study of women entrepreneurs", Journal of Organizational Change Management, Vol. 17 No. 3, pp. 256-268.

Bruni, A., Gherardi, S. and Poggio, B. (2004b), "Doing gender, doing entrepreneurship: an ethnographic account of intertwined practices", Gender, Work and Organization, Vol. 11 No. 4, pp. 406-429.

Byrne, J., Fattoum, S. and Díaz García, M.C. (2019), "Role models and women entrepreneurs: entrepreneurial superwoman has her say", Journal of Small Business Management, Vol. 57 No. 1, pp. 154-184. 
Byrne, J., Radu-Lefebvre, M., Fattoum, S. and Balachandra, L. (2021), "Gender gymnastics in CEO succession: masculinities, femininities and legitimacy", Organization Studies, Vol. 42 No. 1, pp. 129-159.

Cesaroni, F.M. and Paoloni, P. (2016), "Are family ties an opportunity or an obstacle for women entrepreneurs? Empirical evidence from Italy", Palgrave Communications, Vol. 2 No. 1, pp. 1-7.

Cesaroni, F.M. and Sentuti, A. (2014), "Women and family businesses. When women are left only minor roles", The History of the Family, Vol. 19 No. 3, pp. 358-379.

Cesaroni, F.M., Pediconi, M.G. and Sentuti, A. (2018), "It's always a women's problem! Microentrepreneurs, work-family balance and economic crisis", Administrative Sciences, Vol. 8 No. 4 , pp. 74-90, doi: 10.3390/admsci804007.

Chasserio, S., Pailot, P. and Poroli, C. (2014), "When entrepreneurial identity meets multiple social identities. Interplays and identity work of women entrepreneurs", International Journal of Entrepreneurial Behaviour and Research, Vol. 20 No. 2, pp. 128-154.

Colombo, M. and Salmieri, L. (2020), The Education of Gender the Gender of Education. Sociological Research in Italy, Associazione "Per Scuola Democratica", Rome, available at: https://www.aissociologia.it/?p=4096.

Díaz García, M.C. and Welter, F. (2013), "Gender identities and practices: interpreting women entrepreneurs' narratives”, International Small Business Journal, Vol. 31 No. 4, pp. 384-404.

Eisenhardt, K.M. (1989), "Building theories from case study research", Academy of Management Review, Vol. 14 No. 4, pp. 532-550.

Eisenhardt, K.M. and Graebner, M.E. (2007), "Theory building from cases: opportunities and challenges", Academy of Management Journal, Vol. 50 No. 1, pp. 25-32.

Essers, C. and Benschop, Y. (2007), "Enterprising identities: female entrepreneurs of Moroccan or Turkish origin in The Netherlands", Organization Studies, Vol. 28 No. 1, pp. 49-69.

Fernandes, E. and Mota-Ribeiro, S. (2017), "Respect and self-determination women entrepreneurs' identities and entrepreneurial discourses", Gender in Management: An International Journal, Vol. 32 No. 1, pp. 66-80.

Gillis-Donovan, J. and Moynihan-Bradt, C. (1990), "The power of invisible women in the family business", Family Business Review, Vol. 3 No. 2, pp. 153-167.

Greenhaus, J.H. and Powell, G.N. (2006), "When work and families are allies: a theory of work-family enrichment", Academy of Management Review, Vol. 31 No. 1, pp. 72-92.

Greenhaus, J.H. and Powell, G.N. (2011), "The family-relatedness of work decisions: a framework and agenda for theory and research", Journal of Vocational Behavior, Vol. 20 No. 2, pp. 246-255.

Hamilton, E. (2014), "Entrepreneurial narrative identity and gender: a double epistemological shift", Journal of Small Business Management, Vol. 52 No. 4, pp. 703-712.

Henry, C. (2009), "Women and the creative industries: exploring the popular appeal", Creative Industries Journal, Vol. 2 No. 2, pp. 143-160.

Henry, C., Foss, L. and Ahl, H. (2016), "Gender and entrepreneurship research: a review of methodological approaches”, International Small Business Journal, Vol. 34 No. 3, pp. 217-241.

Hollander, B.S. and Bukowitz, W.R. (1990), "Women, family culture, and family business", Family Business Review, Vol. 3 No. 2, pp. 139-151.

Hytti, U., Alsos, G.A., Heinonen, J. and Ljunggren, E. (2017), "Navigating the family business: a gendered analysis of identity construction of daughters", International Small Business Journal, Vol. 35 No. 6, pp. 665-686.

ISTAT (2016), "I tempi della vita quotidiana: anno 2014", Rome, available at: https://www.istat.it/it/ files/2016/11/Report_Tempidivita_2014.pdf. 
IJEBR

27,4

Jennings, J.E. and McDougald, M.S. (2007), "Work-family interface experiences and coping strategies: implications for entrepreneurship research and practice", Academy of Management Review, Vol. 32 No. 3, pp. 747-760.

Jimenez, R.M. (2009), "Research on women in family firms: current status and future directions", Family Business Review, Vol. 22 No. 1, pp. 53-64.

Jones, R., Latham, J. and Betta, M. (2008), "Narrative construction of the social entrepreneurial identity", International Journal of Entrepreneurial Behaviour and Research, Vol. 14 No. 5, pp. 330-345.

Karhunen, P., Olimpieva, I. and Hytti, U. (2017), "Identity work of science-based entrepreneurs in Finland and in Russia", Entrepreneurship and Regional Development, Vol. 29 Nos 5-6, pp. 544-566.

Kaslow, F.W. (1998), "Handling transitions from mother to son in the family business: the knotty issues", Family Business Review, Vol. 11 No. 3, pp. 229-238.

Leung, A. (2011), "Motherhood and entrepreneurship: gender role identity as a resource", International Journal of Gender and Entrepreneurship, Vol. 3 No. 3, pp. 254-264.

Lewis, P. (2006), "The quest for invisibility: female entrepreneurs and the masculine norm of entrepreneurship", Gender, Work and Organization, Vol. 13 No. 5, pp. 453-469.

Lewis, P. (2013), "The search for an authentic entrepreneurial identity: difference and professionalism among women business owners", Gender, Work and Organization, Vol. 20 No. 3, pp. 252-266.

Lewis, P. (2014), "Postfeminism, femininities and organization studies: exploring a new agenda", Organization Studies, Vol. 35 No. 12, pp. 1845-1866.

Lewis, K.V. (2015), "Enacting entrepreneurship and leadership: a longitudinal exploration of gendered identity work", Journal of Small Business Management, Vol. 53 No. 3, pp. 662-682.

Lomazzi, V. (2017), "Gender role attitudes in Italy: 1988-2008. A path-dependency story of traditionalism", European Societies, Vol. 19 No. 4, pp. 370-395.

Miles, M.B., Huberman, A.M. and Saldana, J. (2014), Qualitative Data Analysis. A Methods Sourcebook, Sage Publications, CA.

Nicholson, N. (1984), "A theory of work role transitions", Administrative Science Quarterly, Vol. 29 No. 2, pp. 172-191.

Ozasir Kacar, S. and Essers, C. (2019), "The interplay between identity construction and opportunity structures: narratives of Turkish migrant women entrepreneurs in The Netherlands", International Small Business Journal, Vol. 37 No. 7, pp. 713-731.

Pettigrew, M. (1997), "What is a processual analysis?", Scandinavian Journal of Management, Vol. 13 No. 4, pp. 337-348.

Poggesi, S., Mari, M. and De Vita, L. (2016), "What's new in female entrepreneurship research? Answers from the literature", International Entrepreneurship and Management Journal, Vol. 12 No. 3, pp. 735-764.

Polkinghorne, D.E. (1991), "Narrative and self-concept", Journal of Narrative and Life History, Vol. 1 Nos 2-3, pp. 135-153.

Reissman, C. (2001), "Analysis of personal narratives", in Gubrium, J.F. and Holstein, J.A. (Eds), Handbook of Interviewing, SAGE Publications, London, pp. 695-710.

Rosenthal, G. (1993), "Reconstruction of life stories: principles of selection in generating stories for narrative biographical interviews", The narrative study of lives, Vol. 1 No. 1, pp. 59-91.

Sentuti, A., Cesaroni, F.M. and Cubico, S. (2019), "Women and family firms: a state of the art literature review", in Laveren, E., Blackburn, R., Hytti, U. and Landström, H. (Eds), Rigour and Relevance in Entrepreneurship Research, Resources and Outcomes, Edward Elgar, Cheltenham, pp. 48-68.

Siggelkow, N. (2007), "Persuasion with case studies", Academy of Management Journal, Vol. 50 No. 1, pp. 20-24. 
Stirzaker, R. and Sitko, R. (2019), "The older entrepreneurial self: intersecting identities of older women entrepreneurs", International Journal of Entrepreneurial Behavior and Research, Vol. 25 No. 8, pp. 1748-1765.

Sveningsson, S. and Alvesson, M. (2003), "Managing managerial identities: organizational fragmentation, discourse and identity struggle”, Human Relations, Vol. 56 No. 10, pp. 1163-1193.

Swail, J. and Marlow, S. (2018), “Embrace the masculine; attenuate the feminine'-gender, identity work and entrepreneurial legitimation in the nascent context”, Entrepreneurship and Regional Development, Vol. 30 Nos 1-2, pp. 256-282.

Wagner, I. and Wodak, R. (2006), "Performing success: identifying strategies of self-presentation in women's biographical narratives”, Discourse and Society, Vol. 17 No. 3, pp. 385-411.

Watson, T.J. (2008), "Managing identity: identity work, personal predicaments and structural circumstances”, Organization, Vol. 15 No. 1, pp. 121-143.

Welter, F. and Smallbone, D. (2010), “The embeddedness of women's entrepreneurship in a transition context”, in Brush, C.G., de Bruin, A., Gatewood, A.J. and Henry, C. (Eds), Women Entrepreneurs and the Global Environment for Growth: A Research Perspective, Edward Elgar, Cheltenham, pp. 96-116.

Yin, R.K. (2003), Case Study Research: Design and Methods, 3rd ed., Sage, Thousand Oaks, CA.

\section{Corresponding author}

Annalisa Sentuti can be contacted at: annalisa.sentuti@uniurb.it
Fading and transformation

For instructions on how to order reprints of this article, please visit our website:

www.emeraldgrouppublishing.com/licensing/reprints.htm

Or contact us for further details: permissions@emeraldinsight.com 